УДК 821.163.41-31.09 Кош Е. https://doi.org/10.18485/godisnjak.2021.16.8

Јована Б. Сувајшић*

Универзитет у Београду

Филолошки факултет, докторанд
Оригинални научни рад

Примљен: 25. 09.2021.

Прихваћен: 05. 11. 2021.

\title{
РЕЦЕПЦИЈА РОМАНА ВЕЛИКИ МАК ЕРИХА КОША И ПОЕТИКА „СОЦИЈАЛИСТИЧКЕ САТИРЕ”
}

У раду је најпре скициран регресивни преображај сатире у совјетској књижевности из развијеног облика током двадесетих и почетком тридесетих година XX века у периферну књижевну појаву у периоду доминације догматског социјалистичког реализма. Раније назнаке те промене лоцирају се у текстовима критичара Владимира Блума из 1925. године и из 1929. године, при чему други текст представља део значајне дебате о социјалистичкој сатири вођене на странама журнала Кюижевна газета. Ова дебата открива неслагања критичара по питању потребе за сатиром у социјалистичком друштву и у први план истиче захтев да сатира мора одражавати напредне тековине социјализма, наговештавајући будући услов опстанка сатиричног писања у епохи социјалистичког реализма. У другом делу рада скренута је пажња на текстове и дебате из којих се може реконструисати својеврсна неформална поетика послератне југословенске сатире. Под још јаким утицајем социјалистичког реализма као „исправног" модела одношења књижевног дела према стварности, у поменутим текстовима преиспитиване су специфичности социјалистичке сатире, где се запажа претрајавање недоумица совјетских критичара из половине и с краја двадесетих година XX века, нарочито у погледу упитне „конструктивности" сатире у социјализму. Рецепција послератног сатиричног романа Велики Мак Ериха Коша сагледава се у контексту тих недоумица,

*jovana.suvajdzic@gmail.com 
односно проверава се у којој су се мери судови критичара у приказима Кошевог романа заснивали на тој неформалној поетици.

Кључне речи: Ерих Кош, Велики Мак, сатира, Владимир Блум, социјалистички реализам, књижевна критика.

Сатирични роман Ериха Коша Велики Мак (Чудновата повест о киту великом такође званом Велики Мак) објављен је 1956. године. То је био први у низу сатиричних романа које ће написати овај писац. Кошево дело сатиричним транспоновањем догађаја из 1953. године - београдске изложбе кита уловљеног на Пагу, која је уследила након изложби у Ријеци, Љубљани и Загребу (в. Борба, 15. фебруар 1953) - дочарава и подсмеху излаже помаму Београђана за изложеном егзотичном животињом.

У јеку полемика које су се тицале ослобађања критичког суда од догматских притисака, дневна критика је дочекала наведену сатиру са знатним ентузијазмом: током 1956. и 1957. године прикази Великог Мака били су објављени у ондашњим истакнутим часописима и листовима (НИН, Политика, Борба, Младост, Ослобођење, Кьижевне новине, Поља, Савременик, Побједа итд.) (Марковић 2008: 75-77). До појаве Великог Мака Кош је био књижевној јавности познат као писац збирки приповедака У ватри (1947), Три хронике (1949), Записи о младим људима (1950), Крушевички кнез (1952), Време: ратно (1952), Најлепше године (1955). Након Великог Мака наставио је с писањем сатире кратким романима Снег и лед (1961), Врапцуи Ван Пеа (1962) и Имена (1964).

Поглавито повољне реакције критичара на Кошево опредељење за сатиру и њихове процене о већој литерарној вредности Великог Мака у односу на ране приповетке засигурно су охрабриле пишчева даља истраживања сатиричног књижевног облика. ${ }^{1}$ Према сведочењу самог Коша у есеју „Слобода и сатира” (1958), већ је Велики Мак изменио пишчев поетички профил учинивши га „стручњаком” за сатиру у виђењу књижевне заједнице:

\footnotetext{
${ }^{1}$ Према Радојици Таутовићу, „Велики Мак наговештава извесне Кошеве стваралачке могућности, које, не само степеном већ и врстом, очито надмашују његова ранија остварења" (Таутовић 1957: 611). Драган М. Јеремић приказ Великог Мака завршава тврдњом да „[о]вим својим делом Кош је открио један свој драгоцени таленат, таленат за алегорију, за интелектуално фино компоновану сатиру, за добро запажање које се ставља у службу једне тачне, актуелне и добро нађене идеје" (Јеремић 1956: 3). Ипак, Милован Данојлић примећује како Кошев „текст, иако изнад нивоа новинских хуморески, још нема ону тежину и озбиљности великих сатиричара, још је на известан начин репортерски, педантан, умивен” (Данојлић 1956: 3).
} 
Откако се пре отприлике годину и по дана у књижарским излозима појавила танка књижица под дугим насловом „Чудновата повест о киту великом, такође званом Велики Мак”, а поготову откако је наша књижевна критика, у својој потреби за класификацијама, одредила да се поменута књижица има да сврста у књижевну фелу прозе, фамилију приповетке, род сатире, врсте политичко друштвене - од тог доба, дакле, ево већ прилично времена како поједине редакције, новинари, књижевне среде, четвртци и остали књижевни дани недеље, подељени на нашу заједницу градова, једнако од мене, као од специјалисте стручњака, траже изјаве, мишљења, предавања и чланке о сатири (Кош 1985: 13).

Доцније је, у првим књижевноисторијским прегледима послератне епохе (Предраг Палавестра, Послератна српска књижевност 1945-1970), Кош задобио „позицију” својеврсног обновитеља послератне сатиричне књижевности (Палавестра 2012: 405). Овде треба подсетити да је сатира представљала неуралгичну тачку послератне књижевности - и за писце и за критичаре - од појаве „Јеретичке приче” Бранка Ћопића (1950), те да је од тада била „осуђена” на „гето кабареа и хумористичких листова” (Миочиновић 1986: 10-11, Richter 2018: 162) попут Јежа. За појединце непотребна књижевна врста у социјализму, за друге симбол и показатељ степена слободе у друштву, ${ }^{2}$ сатира је педесетих година и почетком шездесетих година била „несигуран терен” за писце и критичаре. Неким од ових виђења и тумачења сатире посветићемо више пажње у наставку рада. Преиспитивање услова за постојање (или, боље рећи, опстајање) сатире у социјализму нарочито је дошло до изражаја на састанку Основне организације Савеза комуниста Удружења књижевника Србије одржаном 13. децембра 1955. године са главном тачком дневног реда „Сатира и друштвена стварност" (уп. Пековић 2000: 38-52, 129-134).

О значају сатире као неофицијелне историје, жанра који је имплицитно откривао „мрачне стране” друштвеног живота, говорио је Милован Витезовић на округлом столу „Сатира у савременој књижевности” 1980. године:

Сатирична књижевност [...] служи и да, кад прође неко време, утврдимо и какво је то време било. Книжевну археологију утврђујемо на основу рада сатирича$p a$. Нама не пада на памет да узмемо, рецимо, романе Владана Ђорђевића, и да посматрамо владавину Обреновића кроз бројне оде и поеме о Милану, о Обреновићима, али се везујемо за Домановићеве сатире, за Дисове „Наше дане” (Ред. 1980: 13; курзив Ј. С.).

${ }^{2}$ УП. Tomislav Ketig, „O satiri i njenoj ulozi danas”, Delo, god. II, br. 11, str. 1345-1350; Др Светозар Стојановић, „Тезе о нашој сатири: Право на сатиру не може се поклонити”, Политика, год. LX, бр. 17941, стр. 3; „Разговор у редакцији: Сатира у савременој књижевности”, Кюижевне новине, год. ХХХІІ, бр. 600, 1980, стр. 12-15. 
Уколико сатира представља драгоцен извор за „књижевну археологију”, на истоврсан начин рецепција сатире открива слободоумност књижевне заједнице, па и, шире посматрано, друштва, њихову отвореност за критичке „убоде” и увиде. Као и сама сатира, критичко писмо о сатири открива дубље књижевне и друштвено-политичке напетости.

У овом раду ћемо настојати да у контексту критичких текстова о сатири у послератној југословенској књижевности растумачимо судове неких од тадашњих водећих критичара поводом Великог Мака Ериха Коша. Први текстови критичара о сатиричној књижевности у послератној Југославији заснивају се на традицији критичког писања о сатири произашлој из поетике социјалистичког реализма тридесетих година у Совјетском Савезу. Како ћемо тежити да покажемо, упркос таласу дискусија које су у југословенском књижевном животу водиле ка ослобађању критике након периода директног критичког прописивања ${ }^{3}$, наноси тог догматског, полизитованог говора о сатири примећују се и 1956. и 1957. години, у приказима романа Велики Мак.

Критички текстови на које ћемо се најпре позивати јесу прикази романа Велики Мак који су пратили објављивање Кошевог дела 1956. године: Драган М. Јеремић, „Ерих Кош: 'Велики Мак' (Издање Матице српске, 1956)”, Борба, год. XXI, бр. 268, 9. октобар 1956, стр. 3; В., „Ерих Кош: 'Велики Мак' (Издање 'Матице српске', Нови Сад, 1956), Народна армија: лист Југословенске народне армије, год. ХІІ, бр. 902, 25. октобар 1956, стр. 10; Витомир Вулетић, „Ерих Кош: 'Велики Мак': Матица српска - 1956", Поља, год. ІІ, бр. 16-17, октобар - децембар 1956, стр. 8; Маријан Јурковић, „Сатира, најзад: Ерих Кош: Чудновата повест о Киту Великом такође званом Велики Мак; иртежи Мила Милуновића; издање Матиие српске, Нови Сад, 1956", Савременик, год. II, новембар 1956, стр. 538-541; Радојица Таутовић, „Сатир против идола (Е. Кош: 'Чудновата повест о киту великом такође званом Велики Мак', изд. Матице српске, Нови Сад, 1956)", Летопис Матище српске, год. 133, књ. 379, св. 6, јун 1957, стр. 601-611.

${ }^{3}$ Душан Бошковић, као и безмало сви књижевни историчари и проучаваоци који пишу о послератној књижевности, истакао је различитост доминантне естетике у југословенској култури пре 1950. године и након 1950, а нарочито након 1952. године. Он је на следећи начин именовао те „циклусе” стварања: „доба сакрализације”, односно време „прављења свакојаких светиња које су, у принципу, биле заштићене од сваке критике" које је трајало до 1950. године; и „циклус интелектуалне секуларизације”, који „почиње, приближно, од 1950. и траје до краја 1972. године”, при чему не треба мешати интелектуалну са политичком „секуларизацијом”, јер „стварна политичка секуларизација ту није достигнута” (Bošković 2003: 9). 
Основно упориште у представљању послератних југословенских дискусија о сатири биће састанак чланова Основне организације Савеза комуниста Удружења књижевника Србије посвећен могућностима социјалистичке сатире из 1955. године („Сатира и друштвена стварност”). Важне увиде пружиће нам и текстови о сатири писани током преломних тренутака у послератној Југославији, пре разлаза са Совјетским Савезом (текст Јована Поповића „О проблематици сатире на домаћу реакцију (Поводом Куленовићеве комедије 'Вечера')” 1848) и у јеку политичког заокрета (текстови који су пратили објављивање Ћопићеве „Јеретичке приче" 1950. године).

Тачка совјетске „теорије” сатире на коју ћемо се у раду усредсредити јесте питање о „конструктивности” социјалистичке сатире. Заправо, реч је о питању од ког је од средине тридесетих године XX века зависила судбина сатире у Совјетском Савезу: Каква је улога сатиричне критике у социјалистичком друштву? У периоду теоријског и критичког формулисања социјалистичког реализма, та критика није проналазила своје место у совјетској књижевности, сем уколико је нападала остатке старог буржоаског устројства. Аспекти „конструктивности” сатире тицали су се поетике социјалистичког реализма, према којој се социјалистичка сатира морала позитивно одредити тематским уклапањем у ту поетику, укључивањем претежно хумористичких, а не инвективних тонова, обликовањем позитивних књижевних ликова, прослављањем достигнућа социјалистичког друштва итд.

\section{Сатира у Совјетском Савезу током двадесетих и тридесетих} година XX века: „светли” почеци и „конструктиван” крај

Прва постреволуционарна деценија у Совјетском Савезу протиче у знаку борби писаца удружених у различите групације и организације (футуриста и пролетерских група писаца, пре свега) за монопол у књижевном стварању (уп. Лукић 1971: 33-41). Запажа се нови развој прозе - кратке прозе почетком и средином, а романа крајем двадесетих година XX века (Flaker 1988: 21). Пратећи динамику окретања од поезије ка прози, сатирично писање доживљава експанзију у свим популарним књижевним родовима и жанровима - поезији (Мајаковски), комедији (Мајаковски, Булгаков, Катајев, Ердман), краткој прози (Булгаков, Шошченко), фељтону (Зорич, Кољцов), роману (Катајев, Иљф и Петров) (Flaker 1988: 28-29).

Иако је време руског грађанског рата било консолидовало и усмерило пропагандно деловање сатиричара комуниста попут Демјана Бедног 
и Мајаковског ка нападу на контрареволуционаре (Май 1990: 351), врло брзо сатира се морала обрушити на совјетску свакодневицу, на несклад између очекиваног друштвеног и државног развоја у социјализму и послератне кризе која је довела до НЕП-а (Нове економске политике) и повратка капиталистичким облицима економије 1921. године. Та врста „унутрашњеполитичке сатире” (Flaker 1962: 114) исте се године јавља у двема песмама Мајаковског: у песми „О гадовима”, чија су мете другови који су свој марксизам свели на постављање Марксовог портрета на зиду не изменивши своје предреволуционарне навике; у сатири на бесмислен бирократизам комуниста који непрестано „састанче” - „Конференцијаши” (Peters 1984: 45). Два тока сатиричног стварања Мајаковског обележиће управо теме бирократизма и малограђанства; уједно, то су два најзаступљенија предмета совјетских сатира током двадесетих година XX века. ${ }^{4}$

Опортунизам људи који су покушавали да искористе нове економске услове НЕП-а сатирично је тематизовао у краткој прози Михаил Зошченко (Peters 1984: 53). У „Поеми у две тачке с прологом и епилогом” (Flaker 1988: 312) - краткој прози Чичиковљеви доживљаји - Михаил Булгаков оживљава Гогољевог јунака Чичикова, и прати његов успех у бирократизованој совјетској свакодневици која се ни по чему не разликује од гротескног света Мртвих душа. Роман Град Градов Андреја Платонова доноси повест о становницима потпуно бирократизованог, умртвљеног града у руској провинцији (Peters 1984: 69). Иљф и Петров стварају лик Остапа Бендера, пикара који ће просперирати у бирократском совјетском систему и малограђанској средини у романима Дванаест столица и Златно теле (Flaker 1988: 271).

Из наведеног може се закључити да је совјетска власт током двадесетих година толерисала и самокритичну сатиру. Анатолиј Луначарски, народни комесар за образовање (на тој позицији од 1917. године до 1929. године) и најважнији ондашњи поклоник сатире, најгласније је заговарао сатирично писање као оружје класне самодисциплине. Чувени говор Луначарског из 1930. године - „О смеху” - садржи и следеће напомене о друштвено регулационој улози смеха:

Али изван закона постоји још једна сила друштвеног дисциплиновања која кажњава преступе - та сила јесте јавно мњење. Делујући изван законског система, јавно мњење кажњава употребом друштвених средстава. Оно не намеће казне поје-

${ }^{4}$ Листа тема препоручених 1925. године совјетским сатиричарима у часопису Крокодил садржала је четири тачке: домаћа и светска антагонистичка класа (буржоазија, НЕП бизнисмени); пропусти у радничкој класи и сељаштву; неправилности у совјетским организацијама; политичке партије супротстављене диктатури пролетеријата (Ершов 58, Ушакин 2013: 10). 
динцима, групама, или читавој класи користећи се судом, егзекуционерима, или затвором. Па ипак, оно намеће казне осетљиве природе, кроз другачије облике бојкота. Међу њима, смех игра огромну улогу (Lunacharsky, „On Laughter”, Gérin 2018: 201).

Благонаклоност цензорских комисија према сатиричарима, међутим, варирала је од случаја до случаја, од писца до писца. Примерице, Зошченков хумор било је лакше одобрити - чак и када је под образином наивног приповедача износио опаске о системским пропустима совјетског социјализма - него продор застрашујућег и апсурдног у гогољевским сатиричним приповеткама Михаила Булгакова из збирке Ђаволијада (1925) (Peters 1984: 62-63). Једна од Булгаковљевих сатира из овог периода, „Псеће срце”, остала је, тако, необјављена све до шездесетих година, као, уосталом, и Мајстор и Маргарита, роман са снажним елементима сатире.

Упоредо с победом књижевног програма пролетерских удружења (РАПП-а), чији ће захтеви водити, у крајњој консеквенци, од средине тридесетих година, потпуном подређивању стваралаштва партијској политици у оквирима догматског, државног пројекта социјалистичког реализма (уп. Flaker 1988: 30-32), критичари се окрећу преиспитивању природе социјалистичке сатире. Године 1925, када Резолуција Политбироа ЦК СКП(б) „О политици партије у области уметничке литературе” привидно зауставља чарке супротстављених књижевних група и негира повлашћеност било које од тих група у совјетском књижевном животу, а заправо „на мала врата” уводи привилегије пролетерским писцима (Flaker 1988: 30; Милорадовић 2012: 78), Владимир Блум, позоришни и књижевни критичар, члан ГЛАВРЕПЕРТКОМ-а 5 , у тексту „Ка питању о совјетској сатири" (журнал Живот уметности, бр. 30, стр. 2) залаже се за сатиру у којој

[п]редмет сатире [...] не представља друштвено, већ индивидуално; сада сатиричар постаје „моралиста”, приказујући ружну појаву као изузетак, као искривљеност стварности која има све тенденције ка здрављу, ка ведрини - ка норми (Блюм 1925: 2).

На тај се начин (политичка) сатира друштва почиње усмеравати ка (моралистичкој) сатиричној тематизацији понашања појединаца. Наговештавајући будуће замерке које ће сатири упутити заступници социјалистичког реализма, Блум сумња у корисност корозивне сатире када је у питању и даље млад, недовољно развијен социјалистички систем:

${ }^{5}$ ГЛАВРЕПЕРТКОМ (Главный репертуарный комитет) - комисија за цензуру репертоара академских позоришта 
Излишно је и говорити да сада - после Октобра - када је држава постала „наша” - ови [предреволуционарни, гогољевско-шчедриновски сатирични, J. С.] начини никуда не воде. Исмевати, и на тај начин подривати темеље пролетерске државе, ругати се првим, може бити, несигурним и „неспретним” корацима нове совјетске јавности - у најмању је руку непромишљено и неразумно (Блюм 1925: 2).

Блумова бојазан да је сатирично исмевање нејаког савременог друштва неразборито претвара се 1929. године у одлучно порицање потребе за сатиром. Те године, у јеку масовне индустријализације и колективизације коју је књижевност - по налозима РАПП-а - у све већој мери морала подржавати тематски и идејно (Лукић 1971: 145-146), Блум постаје актер дебате која је вођена на страницама Кюижевне газете. Најдрастичнији допринос разговору о сатири овом приликом дао је управо Блум чланком „Хоће ли се сатира поново родити?”, односно ставом да сатира није ефикасно средство за борбу против реакционарних сила и да, штавише, сатири нема места у социјалистичком уређењу:

Класна борба наставља се у новим условима, под новим околностима. У складу с тим огољава се и класна природа једног од њених оруђа - уметничке сатире: наставак традиције дооктобарске сатире (против државе и друштва) већ представља директан ударац по нашој држави, по нашем друштву. [...] Сатирична се традиција завршила - то открива чак и летимична, површна анализа „питања о сатири”. Ово оруђе више не одговара борби против реликата прошлости у нашој држави и друштву (Блюм 1929: 2).

Како сумира Ени Жеран, канадски проучавалац совјетске визуелне пропагандне културе, у књизи Очајање и смех: сатира, моћ и култура у раној совјетској држави, Блумова логика је следећа: сатира је одувек била

употребљавана као оружје уперено ка држави. Али, будући да је Револуција увела власт пролетеријата и сељака, држава више није непријатељ. У контексту успешне изградње „социјализма у једној земљи”, зашто би људи упирали сатиричне стреле против себе самих? (Gérin 2018: 177)

Мада су ове провокативне изјаве пратила три текста ${ }^{6}$ која су негирала Блумову теоријску егзекуцију сатире, и у тим радовима запажа се слагање аутора по питању њене правилне „оријентације” - напада на бирократизам, малограђанство (Јакубовски, „О путевима совјетске сатире”), религију, национализам, доколичарење, кукавичлук (аноним, „О путевима совјет-

${ }^{6}$ Блумов чланак представљао је одговор на раније публикован приказ сатиричног романа Андреја Новикова, чији је аутор био књижевни критичар Абрам Лежњев („На путу ка обнови сатире”); део дебате чинили су и текст „О сатири наших дана” Георгија Јакубовског, чланак „О путевима совјетске сатире” анонимног писца, рад М. Рогија „Путеви совјетске сатире” и извештај Ефима Зозуље (под насловом „Да ли нам је потребна сатира?”) са округлог стола одржаног 1930. у Политехничком музеју (Gérin 2018: 176-180). 
ске сатире") (уп. Gérin 2018: 176-180). М. Роги, међутим, у делимичном сагласју с Блумом, текстом „Путеви совјетске сатире” доноси предлог који ће касније, у ери социјалистичког реализма, бити усвојен као званична „теорија” социјалистичке сатире:

Друг Блум у једном има право. Сатира не би требало да ломи младище, да краде плодове, а камоли да поткопава корене совјетског система. Овде је умесно говорити и о партији, синдикатима и волонтерским организацијама. Сатира, уколико је одиста совјетска, не може заобићи све ове организаиије, не може не показати њихову позитивну улогу у борби против штетних реликата прошлости у нашој држави и друштву. (Роги 1929: 3; курзив Ј. С.).

Тако сатира, у периоду свог највећег развоја, крајем двадесетих и почетком тридесетих година XX века, када совјетска књижевност постаје богатија за низ сатиричних романа (Проневеритељи (1927) Валентина Катајева, Град Градов (1927) Андреја Платонова, Дванаест столица (1928) и Златно теле (1931) Иљфа и Петрова) полако задобија двоструко задужење - „рушилачко” и „конструктивно” (Gérin 2018: 180). Уз критику заосталих схватања и појава (,реликти прошлости”) она одсад мора сагледавати и позитиван утицај социјалистичких тековина на друштво и усаглашавати свој садржај према тим увидима.

Залог опстанка сатире у другој половини тридесетих годинама у СССР-у постаје њена „конструктивност” - могућност да се уклопи у поетику социјалистичког реализма, формулисану између 1932. и 1934. године. Иако је Луначарски 1933. године у говору с насловом „Социјалистички реализам" инсистирао на томе да се и у догматичном социјалном реализму може створити простор за сатиричну хиперболу и карикатуру (Gérin 2018: 184), у пракси, сатира у другој половини тридесетих година, након деценије процвата, пролази кроз затишје. Неки писци сатира нестају из књижевног живота. Након смрти Мајаковског (1930) у штампи остају само његове ведрије сатиричне песме (Peters 2003: 215). Замјатин напушта 1931. године Совјетски Савез.

Сатиричарима је било тешко да удовоље захтевима идеолога социјалистичког реализма попут Жданова. Најважнији од тих захтева тицао се визије која се посредује делом: књижевно дело морало је изражавати оптимистичну визију живота у социјализму. Када су уочавани неки недостаци у социјалистичком друштву, књижевницима је указивано на то да њихово дело мора пре свега узети у обзир перспективу будућег успешног развоја социјализма. ${ }^{7}$ Из те перспективе, дефекти савремености били су

${ }^{7}$ Ервин Шинко тај парадокс формулише далеко успешније: ,'Социјалистички реализам је умјетност, која захтијева од умјетника да, привржен стварности, изрази стварност, али не 
пролазни. Сатира је тако била „укроћена”, а сатиричари су се морали окренути безазленијем хумору.

Поједини писци нису ни покушавали да то учине. Булгаковљев волатилан однос са цензуром ${ }^{8}$ наставља се и у тридесетим годинама; упркос томе, 1937. године он пише Позоришни роман, сатиру на тему цензуре. Зошченко наизглед подлеже критичким притисцима, те у своју Плаву књигу (1935) - додуше, скривен иза дотад често коришћене маске приповедача у првом лицу, где су приповедачеви коментари могли бити иронични (уп. Peters 2003: 218-220) - укључује сегменте који су величали међуљудске односе у социјализму. Ни то га, међутим, није спасило осуде главног теоретичара социјалистичког реализма, Владимира Жданова, у Резолуцији ЦК СКП(б) из 1946. године због писања „празних, бесадржајних и тривијалних ствари" (Flaker 1962: 334). Том приликом искључен из Савеза совјетских писаца, Зошченко ће 1953. године поново постати његов члан. У периоду „отопљења” након Стаљинове смрти сатира ће изнова постати популаран жанр посредством ког ће се млађе генерације писаца, не одмичући се, ипак, далеко од поетике социјалистичког реализма, „критички суочити са стаљинистичком прошлошћу” (Peters 1984: 117).

\section{Рецепција романа Велики Мак у контексту неформалне поетике југословенске социјалистичке сатире}

Истовремено, почетком шесте деценије XX века, у младом социјалистичком друштву Југославије, кроз велики броја расправа, напором писаца и критичара одбацивана је доктринарна поетика социјалистичког реализма. Ипак, и поред промене доминантног уметничког стила, увођења плурализма уметничких стилова, уметничко се стварање и даље морало саображавати политичким потребама партије. Књижевност се и даље „ослањала на политику и служила политичким језиком - признајући, прећутно, још врло дуго, врховну арбитражу партијских форума - књижевност је прихватила подређен друштвени положај и супрематију ванкњижевних структура" (Палавестра 2012: 143).

као њен заробљеник, него с перспективом будућности пред очима”” (Ervin Šinko, „Kulturna baština i socijalistički realizam”, Bošković 2003: 48).

${ }^{8}$ Године 1929. забрањено је извођење свих драмских дела које је дотад написао Булгаков. Очајан, Булгаков је написао писмо влади Совјетског Савеза, чији је крајњи реципијент био Стаљин. Булгаков се у овом писму жалио на немогућност рада у Совјетском Савезу и затражио допуштење да напусти земљу. После једног Стаљиновог позива више није било речи о Булгаковљевом одласку - писац је остао запослен у Московском уметничком театру и током тридесетих година (уп. Richmond 2006). 
Непромењен је био и однос критике према сатири наслеђен прихватањем поетике социјалистичког реализма. Пре сукоба с Информбироом суштина тог односа очита је у тексту Јована Поповића „О проблематици сатире на домаћу реакцију (Поводом Куленовићеве комедије 'Вечера')" (Кюижевне новине, год. I, бр. 39, 1948, стр. 3). Новоосноване Кюижевне новине амбициозно су намериле да у првој години свог излажења читаоцима свестрано представе осамдесет пет тема које су се тицале културног напретка југословенских социјалистичких друштава (Dimić 1988: 217). Иако напослетку нису успели у већој мери у том циљу, ${ }^{9}$ можемо претпоставити да је једна од тих „горућих” тема културног живота била и писање сатире, те да је текст Јована Поповића имао за циљ да критиком позоришног извођења Куленовићеве комедије „Вечера” сугерише писцима и читаоцима која је правилна идејна оријентација сатире, као и ко би се морао наћи на њеној мети.

Неминовно, права мета сатире јесте „домаћа реакција” (Popović 1948: 3), односно то су реликти прошлости који су фигурирали и у раније наведеним текстовима совјетских критичара. За нас је, међутим, важнији следећи пасус, којим се сатири поставља познати захтев о рушилачкој (у односу на остатке грађанског друштва) и конструктивној (у приказивању снаге и надмоћи социјалистичког друштва над „прежицима”) улози:

Међутим, кад писац хоће да прикаже неумитно сламање покушаја камуфлираних непријатеља у новој друштвеној стварности, он мора [...] не само показати снагу новог друштвеног уређењ $а$, него, да не би неправедно приказао народну власт слепом и неспособном - што она није, он мора и те уљезе приказати онако да буде могућна обмана коју они привремено врше. Ту писац није успео. Није довољно приказао типичне околности, својим негативним личностима није супротставио уверљиво претставнике новога, а те претставнике старога, негативнога он је приказао тако очито и банално покваренима да постаје невероватно да су они могли обманути народну власт, изиграти масовне организаџије и радничку класу, а очитост њиховог личног нитковлука [...] не допушта да се у правој мери покаже снага и морална величина новога друштва које они хоће да компромитују и руше (Popović 1948: 3; курзив J. С.).

У другом важном тренутку, 1950. године, док је сукоб с Информбироом прерастао у потпуно разилажење двеју социјалистичких земаља, а на културном плану долазило до отклона од естетике социјалистичког реализма, сатира је још једном морала бити враћена на правилан идејни колосек. Овог пута у питању је била „Јеретичка прича” Бранка Ћопића.

\footnotetext{
${ }^{9}$ Како наводи Љубодраг Димић у књизи Агитпроп култура: агитпроповска фаза културне политике у Србији на основу Извештаја о Кьижевним новинама из 1948. године, поднетог у ЦК СКЈ, „[К]рајњи резултат је био поразан, јер сем неколико, ниједна од понуђених и датих тема није била обрађена" (Dimić 1988: 217). s
} 
Ћопићеву причу о повластицама које на летовању уживају високи државни функционери, о притворности њихових односа и немерљивости њихових амбиција, снажно су - из аспекта истинитости приказаног - оспорили Скендер Куленовић, Душан Поповић, Велибор Глигорић и анонимни писац два текста у два броја листа Борба. ${ }^{10}$ „Истинитост” књижевног дела била је у првим послератним годинама самеравана према типичности донетих ликова и ситуација у делу, у складу са нормама социјалистичког реализма. Ћопићеви ликови у Јеретичкој причи били су оцењени као „нетипични" - на такве људе не наилазимо у савременом социјалистичком друштву (Kulenović 1950: 1). Како смо већ писали, негативне појаве из аспекта континуалног напретка социјализма у друштву нису могле бити типичне, већ локализовани инциденти. Свака критика је стога могла бити побијена тврдњом да су приказане прилике „нетипичне” (Ketig 1962: 1347).

Уз то, Ћопићева сатира недвосмислено је била означена као „штетна” и „неконструктивна” - она није на задовољавајућ начин разрешила дидактички изазов пред којим се у социјализму нашла сатира. Речима Душана Поповића из текста „Клеветничка сатира”,

најнеспретнија сатира може да делује на појединиа, да му укаже на неку његову негативну страну, да га застиди пред самим собом. Али једна оваква „сатира” пре свега је штетна: она својом неистинитошћу може да пробуди и у добронамерном читаоцу расположења која неће допринети изграђивању једне чврсте друштвене заједнище (Popović 1950: 3; курзив J. С.).

Силином негативне реакције на појаву „Јеретичке приче”, наведени критичари засигурно су утицали на каснију динамику (не)писања сатиричних дела у југословенској књижевности. Након „Јеретичке приче”, сатира је била готово сасечена у корену. Писци су мудро препознали наравоученије Ћопићевог „случаја” - било је најпаметније не писати сатиру. ${ }^{11}$ Постепено попуштање стега догматског обруча око уметника и њихових дела није значило да је притисак ауторитарне критичке контроле нестао:

${ }^{10}$ Уп. Скендер Куленовић, „Истина и слобода”, Кюижевне новине, год. III, бр. 35, стр. 1-2; Душан Поповић, „Клеветничка сатира”, Кюижевне новине, год. III, бр. 43, стр. 2-3; Велибор Глигорић, „'Јерес' Бранка Ћопића”, Књижевне новине, год. III, бр. 47, стр. 3; Аноним, „'Јунаштво' Бранка Ћопића”, Борба, год. XV, бр. 257, стр. 2. и бр. 258, стр. 2.

${ }^{11}$ Палавестра цитира Лукићеве закључке на ову тему: „’За разлику од совјетског догматизма' - каже Света Лукић - 'у коме бирократија наређује уметницима да на одређен начин нешто ураде, код нас се друштво у лицу политичара и идеолога са уметницима договара или им поручује шта да не ураде"” (Палавестра 1983: 22). 
Проблем мере у контроли начелно је нерешив за социјалистички реализам. Стога, уз непромењен склоп доктринарних циљева, контрола може добијати различите димензије, тј. неизбежна је произвољност. Као природна последица, одатле следи опште осећање несигурности међу уметницима. Чак и кад желе да следе неки пропис у свом стварању, никада не могу бити сигурни да ли то адекватно чине (Bošković 2003: 91).

Нису могли - у случају сатире - бити сигурни како ће њихова сатира бити оцењена, нити да ли ће у њој бити пронађен неки штетан, назадан, реакционаран елемент. Стога је, такође, било најмудрије не писати сатиру.

Упоредо са истраживањем и покушајима изналажења другачијег пута југословенског социјализма и југословенске књижевности након разлаза са СССР-ом, средином 50-их година појавило се и питање о посебностима југословенске социјалистичке сатире. Помало иронично, ни питања ни одговори нису се много разликовали од оних који су били предочени совјетским дебатама. Према Ћопићу, који је дебату иницирао, требало је једном рашчистити с тим

какав став треба заузети према једној негативној појави, како и до које мјере је критиковати, једном ријечју: докле отићи у критици и раскринкавању, а да та критика још увијек сачува свој стваралачки и напредан став, а да се не претвори у критику убицу, у непријатељско исмијавање нас и наших подухвата (Пековић 2000: 131; курзив J. С.).

Ублажавајући блумовски став да је сатира била природна појава у капитализму, али да то не важи и за социјализам, Ћопић ипак истиче да постоје знатне разлике између сатире у грађанском и у социјалистичком друштву:

Раније, у старом друштву, писац сатиричар ударао је сатиром по разним манама и негативним појавама једног поретка, био је његов љекар и исијелитељ, али је исто тако могао да заузме стопосто негативан став према читавом поретку и да се претвори у његовог рушитеља. [...] Данас код нас, у соиијалистичком друштву, писаи комуниста може и мора да буде само оно прво: писац који ће својом сатиром шибати све мане и негативне појаве које се јављају у оквиру нашег друштва и теже да нагрде и извитопере и лик нашег човјека и лице социјализма (Пековић 2000: 130; курзив J. С.).

Прилично унисоно, учесници дебате давали су своје виђење о томе шта сатира не треба бити да би била конструктивна. Њихови ставови одражавали су гледишта изнета у совјетској дебати 1929. године. Индикативна у том смислу јесте дескриптивна и суштински неодређена подела Ота Бихаљи-Мерина на „велику” и „малу” сатиру. Ратко Пековић, који у књизи Суданије Бранку Ћопићу доноси изводе из Стенографских бележака датог састанка организације УКС, пише да 
[п]осматрајући данашње време и свет као једну целину, са мноштвом трагике и гротеске, Ото Бихаљи-Мерин сматра смешном тврдњу да се сада не може правити сатира, али истовремено закључује да „, велика сатира” није примерена социјализму. [...] Само „касно”, „старије” друштво, вели Бихаљи-Мерин, може да се смеје ономе што је битно и само оно, донекле, трпи и ону убитачну сатиру. „Ја мислим да један млад покрет, нешто ново, што се гради, нема у себи потребу да се у његовим стварима смеје” (Пековић 2000: 45).

Шта би биле у том контексту „мала” и „велика” („убитачна”) сатира ако не хумористична књижевност или сатира чија је оштрица отупела насупрот правој, инвективној сатири? Нешто отвореније, Младен Ољача признаје да у младом социјалистичком друштву важи да „’неке теме [...] морамо, као комунисти, одлагати"” (Пековић 2000: 46).

Тако је конструктивна сатира у југословенском социјализму требала бити „исцелитељска” и „мала”. Поглед уназад на стање у ком се налазила сатирична књижевност педесетих година доноси Предраг Палавестра књигом Послератна српска књижевност 1945-1970. Силом прилика „смањена”, „[п]ринуђена на тегобна прилагођавања и на мучно вегетирање на нивоу безазлених пошалица са људима без одбране, она [сатира, J. С.] се окренула хумору и бурлески" (Палавестра 2012: 404).

Конструктивност Кошеве сатире Велики Мак оно је што га, у приказу Маријана Јурковића из 1956. године, издваја и чини пиониром социјалистичке сатире:

Од Четрдесет пете имали смо неколико покушаја сатире и неколико усамљених резултата, али нико до Коша није тако отворено и, што је најбитније, тако недвосмислено конструктивно поставио сатиру, то значи писао је са љубављу у првом плану. Она код Коша може да буде и треба да буде још одређенија, још оштрија, још суровија [...] јер је конструктивност залога њеног успјеха, громобран у вјечито олујним предјелима њеног кретања напријед” (Јурковић 1956: 540; курзив Јурковић).

И поред жељних повика за „суровијом” сатиром, велики број критичара није пропустио да укаже на суштински песимистичан - дакле, не тако конструктивно постављен - фикционални свет Великог Мака и обесхрабрујућу поруку коју је роман остављао читаоцима. За Витомира Вулетића, туробност Кошеве књиге остаје као најјачи читалачки утисак:

Има нечег тешког, суморног у овој невеликој књижици. Тешког од свакодневнице сиве, млохаве, која је задовољна тиме што је таква. То све притиска, и када човек ову књигу прочита, он не осети никакав бол, већ осети како га потмуло бриди читаво тело и читаво биће. Све је сиво, загушљиво, суморно (Вулетић 1956: 8). 
Радојица Таутовић даје двоструку процену краја Кошевог романа - наизглед песимистичном завршетаку дела овај критичар приписује супротно, борбено тумачење:

Кит се распао; један кумир је пао; али, после Великог Мака, на његово место одмах се диже целулоидна икона Маме Хуаните [...] Као да се Кошова сатирична књижевна креаиија оглушила о грлате заповести и ,, оптимистичке” теорије ,,соиијалистичког реализма". У ствари, Велики Мак наговештава неминовност „борбе непрестане" против исконске људске глупости (Таутовић 1957: 607; курзив Ј. С.).

Тако се очувава начелна „конструктивност” Кошеве сатире: крај није обесхрабрујућ, он позива на сталну будност читалаца пред глупошћу. У приказима су се, међутим, јављале и сличне опаске које су се тицале лошег, „неконструктивног” обликовања главног лика.

Поетика социјалистичке сатире - совјетске и југословенске предвиђала је малограђане, бирократе, капиталисте, припаднике реакционарних струја као типичне „жртве” сатиричних напада. Анатолиј Луначарски је сажето изразио позицију читалаца сатире - они су победници, сатира изазива смех победника над побеђенима. ${ }^{12}$ Како се ту, међутим, уклапао лик сатиричног резонера, фигуре која разобличава понашање исмејаних ликова у име норме коју заступа сатиричар?

Један од најважнијих задатака књижевних дела која су тежила да се уклопе у поетику социјалистичког реализма било је стварање позитивног лика, лика

у коме су, према теорији социјалистичког реализма, сједињене врлине носиоца комунистичког идеала и који, као оваплоћење принципа партијности, има васпитну снагу примера будући да су у њему концентрисана најбоља својства најнапреднијих представника епохе (Палавестра 2012: 273).

На састанку у Удружењу књижевника Србије посвећеном сатири јавило се и питање позитивних јунака. У Пековићевом представљању тог разговора издваја се став Младена Ољаче, који „допушта романсијерима да стварају негативне јунаке јер ти јунаци делују ограничено, у широкој форми, док се у случају сатире увек мисли на 'уопштеност у друштву"' (Пековић 2000: 46; курзив Ј. С.).

Према приказима Кошевог романа, његов јунак, Раде Деспић, далеко је од позитивног јунака. Радојица Таутовић види у главном лику

${ }^{12}$ „'Сатиричар се разликује од озбиљног публицисте у томе што он жели да се сместа смејете овом злу, дајући вам тиме до знања да сте ви победник, да је ово зло мизерно, слабо и да не заслужује озбиљну пажњу, да је далеко испод вас, да га можете отписати смехом, да сте морално супериорни у односу на ово зло"” (Lunacharsky, "Dzhonatan Svift i ego skazka o bochke", Gérin 2018: 33). 
донкихотску, трагичну фигуру, али наглашава да читалац не може у потпуности саосећати с главним ликом будући да „он исто толико припада 'изопаченој реалности', колико јој свешћу и вољом опонира" (Таутовић 1957: 605). Живој нарацији у роману Драган Јеремић супротставља карактеризацију; Кошеви ликови су „мало уопштени и сиви [...] а пре свега главни лик ситног чиновника Деспића, који станује као самац, храни се у рђавој мензи и има интимне односе са туђом женом" (Јеремић 1956: 3). Најоштрији је у својој процени Деспићевог лика писац приказа у Борби, потписан иницијалом В.:

Деспић се суштински не разликује од оних против којих се буни. Уствари, то је друго лище једне исте појаве. [...] Малограђанин једе сам себе у бестијалној оргији тражећи излаза из своје сопствене бесмислености. Излаз нико није намао - ни Раде Деспић, ни гомила која обожава иркнутог кита (В. 1956: 10; курзив Ј. С.).

Суочен с истоврсним нападима на свог јунака, Кош је касније, у различитим приликама, ${ }^{13}$ појашњавао зашто не сматра идеал позитивног јунака могућим у књижевности. Он је најпре полазио од шире књижевноисторијске перспективе, проналазећи примере који доказују да у различитим епохама, на нивоу светске књижевности, није створен успешан, упечатљив, стопостотно позитивни лик:

Нико, дакле, у целокупној нашој старијој, па и новијој реалистичкој прозној књижевности, укључујући Крлежу и Андрића, није нам оставио у наслеђе изразитог позитивног јунака [...] пребирајући сва важнија имена новије светске књижевности у којој, истина, има и идеално добрих, светлих ликова, али, по правилу, само међу споредним, епизодним личностима, или међу анђеоским, рајским душама, добрим и честитим, али ни мало херојским и јуначким, а најчешће помало смешним, па чак и јадним и бедним (Кош 1985: 31).

Ни књижевност социјалистичког реализма, по Кошу, није изузетак - без обзира на нормативност ове теорије, у пракси су ликови партијских и народних, а касније и ратних, хероја били бледи, неуверљиви, ретко успешно обликовани (Кош 1985: 32). Помало иронично, сам аспект идеалности позитивног, напредног јунака није могао ићи у корак с временом. ${ }^{14}$

У својој визији критике савременог живота, Кош је, ипак, допуштао одређене концесије замисли „конструктивности” сатире. Одговарајући на

${ }^{13}$ Уп. Ерих Кош, „Неспоразуми око сатире: разговори с добитницима Октобарске награде”, Кьижевне новине, год. XV, бр. 209, 1963; Ерих Кош, „Позитивни јунак или позитивни писац”, у: Ерих Кош, Сатира и сатиричари, Београд: Просвета, 1985, стр. 28-44.

${ }^{14}$ Кош тако пише да би „,[и]деализовање и популарисање ликова и јунака предратне социјалне литературе, неквалификованих, грубих и примитивних 'рабочих' или фантастичних агитатора за улазак у сељачке радне задруге данас [...] било сматрано не само књижевним већ и друштвеним промашајем” (Кош 1985: 34-35). 
опште упите о прихватљивој мети сатире у есеју „Слобода и сатира” - а који је настао као реаговање на непосредну рецепцију Великог Мака - Кош је моралистичким тоном сатиричара писао да се сатирична осуда сада мора уперити према „нама самима”:

Исмевање четника, Немаца и Талијана, из времена рата, na u „развлаштених остатака некадашње буржоазије” (то су биле теме којима су се наши хумористи, сатиричари и карикатуристи штедро бавили у годинама непосредно после рата), данас би био прилично досадан, јалов и бесциљан посао који би мало кога насмејао а никога ни на шта не би могао да покрене [...] Већ дуже времена је, ево, како смо мање више сами у тој кући, без туђих људи, којих бисмо као сведока могли да се стидимо, довољно смо снажни да бисмо могли да се шалимо и смејемо на свој рачун, без страха да бисмо тиме могли поткопати зграду у којој живимо, а опет исувише смо млади у развоју да бисмо могли не борити се против сопствених дечјих болести и не чувати се зараза које би нам, још недовољно отпорнима, могле нагрдити лице и затровати душу (Кош 1985: 17; курзив J. С.).

Ту је позив на критичко сагледавање тренутка у ком се живи, без позивања на оно што му је претходило. Ипак, ту је такође и смиривање страхова да ће се том сатиричном критиком „поткопати зграда у којој живимо", што указује на претрајавање специфичних бојазни које су пратиле сатиру од средине двадесетих година у Совјетском Савезу и, касније, у послератној Југославији - бојазни на које смо, између осталог, покушали да укажемо у овом раду.

\section{Закључак}

Пут који је сатира имала да пређе у Совјетском Савезу - од подстицања до строгог цензурисања - у југословенској је послератној књижевности, због усвајања поетике социјалистичког реализма, сведен на последњу етапу. Тако је цензура сатире могла достићи своју критичну тачку већ са „Јеретичком причом” Бранка Ћопића. Истовремено, рецепција „Јеретичке приче" био је догађај који је привремено потиснуо даље писање сатире и тиме уједно проузроковао својеврсну „закржљалост” критичког писања о сатири у времену у ком је критика других жанрова (поезије, пре свега) проналазила свој аутентичан, слободан глас.

Од 1950. до 1956. године, када је објављен сатирични роман Велики Мак Ериха Коша, штошта се променило у књижевном животу Југославије. Ипак, у текстовима и разговорима о сатири и даље су се плаћали „поетички дугови” социјалистичком реализму, пре свега у односу на кључно питање: Како написати сатиру која ће подржавати развој социјалистичког друштва? 
Прикази сугеришу да је ово питање снажно заокупљало критичаре при читању Великог Мака, али да су тешко долазили до „правог” одговора. Униформна нелагодност у образложењима које су критичари понудили у односу на упитну „конструктивност” Кошевог романа указује на идеолошку условљеност њихових реакција. Кошев роман је у овим текстовима прослављан као дугоочекивани долазак сатире, али истовремено се примећивала знатна усредсређеност критичара на „сивило” представљеног света, депримирајући ефекат читања романа и разочаравајућу осредњост његовог јунака. Наведене карактеристике биле су у супротности са жељеном дидактичноћу и моралистичким дејством сатире. Ови догматски захтеви били су постављени пред сатиру у Совјетском Савезу опрезније средином двадесетих година, а потом и са сигурношћу цензорске моћи крајем двадесетих и у тридесетим годинама XX века. Како смо тежили да покажемо, истоврсни налози остали су веома актуелни и у расправама о сатири у послератној југословенској књижевности.

Овим радом циљали смо на то да укажемо и на историјску условљеност одабраних критичких текстова - приказа романа Велики Мак. Идеолошка матрица представљених приказа открива се у сродној перспективи критичара, фразама и терминима које су они употребљавали. Тај идеолошки речник, међутим, није био сасвим очигледан све док се није поставио уз раније писане критичке текстове о сатири. Након тих поређења, прикази Кошевог романа су се указали као пригодно сведочанство о једном тренутку у послератној југословенској култури и одличан показатељ стања једног жанра у некадашњем књижевном систему.

\section{ЛИТЕРАТУРА}

Блюм 1925: Владимир Блюм, „К вопросу о советской сатире”, Жизнь искусства, 1925, № 30, с. 2.

Блюм 1929: Владимир Блюм, „Возродится ли сатира?”, Литературная газета, 27. 5. 1929, с. 2.

В. 1956: В. 1956: В., „Ерих Кош: 'Велики Мак' (Издање 'Матице српске', Нови Сад, 1956), Народна армија: лист Југословенске народне армије, год. ХІІ, бр. 902, 25. октобар 1956, стр. 10.

Вулетић 1956: Витомир Вулетић, „Ерих Кош: 'Велики Мак': Матица српска - 1956”, Поља, год. II, бр. 16-17, октобар - децембар 1956, стр. 8.

Данојлић 1956: Милован Данојлић, „Снага сатире и ширина алегорије (Ерих Кош: 'Велики Мак', Матица српска, 1956)', Књижевне новине, год. VII, Нова серија, бр. 27, 28. октобар 1956, стр. 3. 
Јеремић 1956: Драган М. Јеремић, „Ерих Кош: 'Велики Мак' (Издање Матице српске, 1956)", Борба, год. XXI, бр. 268, 9. октобар 1956, стр. 3.

Јурковић 1956: Маријан Јурковић, „Сатира, најзад: Ерих Кош: Чудновата повест о Киту Великом такође званом Велики Мак; иртежи Мила Милуновића; издање Матиие српске, Нови Сад, 1956", Савременик, год. II, новембар 1956, стр. 538-541.

Кош 1985: Ерих Кош, Сатира и сатиричари: чланции и есеји, Београд: Просвета, 1985.

Лукић 1971: Света Лукић, Руска књижевност у соиијализму, Београд: Нолит.

Май 1990: Б. Май, „Русская сатира после 1917-го года”, Zeitschrift für Slawistik, 35 (1990) 3, 351-369.

Марковић 2008: Милена Марковић, Библиографија академика Ериха Коша: у част деведест пет година живота, Београд: САНУ.

Милорадовић 2012: Горан Милорадовић, Лепота под надзором: совјетски културни утицаји у Југославији 1945-1955, Београд: Институт за савремену историју.

Палавестра 1983: Предраг Палавестра, Критичка књижевности: алтернатива постмодернизма, Београд: „Вук Караџић”.

Палавестра 2012: Предраг Палавестра, Послератна српска књижевност 1945-1970 и њена историја, Београд: Службени гласник.

Пековић 2000: Ратко Пековић, Суданије Бранку Ћопићу: (1950-1960), Бања Лука - Београд: Књижевни атеље.

Ред. 1980: Зоран Глушчевић, Славко Лебедински, Зоран Јовановић, Јован Пејчић, Стојан Ђорђић, Милован Витезовић, „Разговор у редакцији: 'Сатира у савременој књижевности"', Книжевне новине, год. 32, бр. 600, 15. март 1980, стр. 12-15.

Роги 1929: М. Роги, „Пути советской сатиры”, Литературная газета, 22. 7. 1929 , с. 3 .

Таутовић 1957: Радојица Таутовић, „Сатир против идола (Е. Кош: 'Чудновата повест о киту великом такође званом Велики Мак', изд. Матице српске, Нови Сад, 1956)", Летопис Матиие српске, год. 133, књ. 379, св. 6, јун 1957, стр. 601-611.

Ушакин 2013: Сергей Ушакин, «Смехом по ужасу»: о тонком оружии шутов пролетариата, Новое литературное обозрение № 121 (2013/3): 130-163.

Bošković 2003: Dušan Bošković, Estetika u okruženju: Sporovi o marksističkoj estetici i književnoj kritici u srpsko-hrvatskoj periodici od 1944. do 1972. godine, Beograd: Institut za filozofiju i društvenu teoriju - „Filip Višnjić”. 
Dimić 1988: Ljubodrag Dimić, Agitprop kultura: agitpropovska faza kulturne politike u Srbiji: 1945-1952, Beograd: Rad.

Gérin 2018: Annie Gérin, Devastation and Laughter. Satire, Power, and Culture in the Early Soviet State, 1920s-1930s, Toronto, Buffalo, London, University of Toronto Press.

Flaker 1962: Aleksandar Flaker, Suvremeni ruski pisci. Knj. 3, Članci i studije o sovjetskoj književnosti, Zagreb: Naprijed.

Flaker 1988: Aleksandar Flaker, Jeretici i sanjari: izbor iz ruske proze dvadesetih godina, Zagreb: Naprijed.

Ketig 1962: Tomislav Ketig, „O satiri i njenoj ulozi danas”, Delo, god. II, br. 11, str. 1345-1350.

Kulenović 1950: Skender Kulenović, „Istina i sloboda: Nekoliko misli povodom Ćopićeve 'Jeretičke priče'”, Književne novine, god. III, br. 35, str. 1.

Peters 1984: Jochen-Ulrich Peters, Russische Satire im 20. Jahrhundert, Verlag: Artemis.

Peters 2003: Jochen-Ulrich Peters, "Satire Under Stalinism: Zoshchenko's Golubaya kniga and M. Bulgakov's Master i Margarita", in: The Culture of the Stalin Period, ed. Hans Günther, Hampshire, New York, Palgrave Macmillan.

Popović 1948: Jovan Popović, „O problematici satire na domaću reakciju (Povodom Kulenovićeve komedije 'Večera')", Književne novine, god. I, br. 39, str. 3.

Popović 1950: Dušan Popović, „Klevetnička satira”, Književne novine, god. III, br. 43, str. 2-3.

Richmond 2006: Steven Richmond, "'And Who Are The Judges?': Mikhail Bulgakov Versus Soviet Censorship, 1926-1936", Russian History/ Histoire Russe, 33, No. 1 (Spring 2006), 83-107.

Richter 2018: Angela Richter, Von der Massenhysterie um einen Wal bis zur Kritik an repressiven Strukturen. Ironische Zuspitzung und groteske Übertreibung bei Erih Koš, Satire und Komik in der bosnisch-herzegowinischen, kroatischen, montenegrinischen und serbischen Literatur, Renate HansenKokoruš / Darko Lukić / Boris Senker (Hrsg.), Hamburg, Verlag Dr. Kovač. 
Jovana B. Suvajdžić

\title{
RECEPTION OF ERIH KOŠ'S NOVEL BIG MAC AND POETICS OF "SOCIALIST SATIRE"
}

\author{
Summary
}

Firstly, the paper outlines the regressive transformation of Soviet satire from a developed literary form in the 1920's and the beginning of 1930's to a peripheral literary phenomenon during the dominance of the dogmatic socialist realism. Earlier signs of that change are found in the texts penned by the Soviet critic Vladimir Blum in 1925. and 1929. The second Blum's text is part of a significant debate on socialist satire that occupied the pages of the newspaper Literaturnaya Gazeta. This debate reveals the disaccord between the critics regarding the need for satire in a socialist society and brings forth the demand for a satire which would reflect the progressive accomplishments of said society, heralding the basic requirements for the survival of satire in the epoch of social realism. The second part of the paper introduces the texts and debates from which a kind of an informal poetics of Yugoslav satire can be reconstructed. In these texts, under the ever-strong influence of socialist realism as the "correct" model for the relationship between literary works and reality, the specificities of socialist satire were reassessed. Said texts also show how long-standing the doubts of Soviet critics from the 1920's were, especially regarding the questionable "constructivity" of satire in socialism. In the final part of the paper the reception of Erih Koš's satirical novel Big Mac is examined in light of these doubts, so as to determine to what extent the critical judgments in the reviews of this novel were based on the aforementioned informal poetics of satire.

Key words: Erih Koš, Veliki Mak, satire, Vladimir Blum, socialist realism, literary criticism. 